\title{
A NOTE ON THE CIVIL REMEDIES OF INJURED CONSUMERS
}

\author{
Albert H. Cotron*
}

From the beginning of the common law, the problem of protecting the consumer from losses caused by defects in food and drugs has faced the courts. While customers have cried to them for protection, business men, probably from the beginning of trade, have lamented that such liability would ruin their business. In dealing with this problem the courts have reflected the spirit of their times. The result has been a changing body of law, and "because the struggles are not wholly over, because the confusion partly still persists, the study of this history has peculiar present value."1

The first approach to the problem in English law was preventive rather than remedial. In medieval times markets were strictly regulated in the interests of the consumers. Regulations extended even to price. They were local and enforced in the local courts. The proceedings were criminal in nature, designed not only to prevent impure foods but unworthy products of all kinds from coming to the market. ${ }^{2}$ There were in addition extra-legal penalties which must have been a powerful deterrent to selling defective goods. The butcher's, the greengrocer's and the apothecary's shops were strictly neighborhood institutions, and the sickness of a customer, whose illness, as all the customers knew, was caused by something purchased at a local shop, would lead to financial losses more terrifying to the proprietor than a judgment for damages. However, the dealer had a real opportunity for knowing what he was selling. His goods were purchased locally and in bulk. These extralegal safeguards have almost entirely disappeared today. A sick customer means little to a national chain store, or to a national manufacturer of food or drug products, unless and until his lawyer appears. And the dealer, in so far as his stock comes in packages or cans, has no more opportunity than the customer to know what he is selling.

The older local regulations broke down with the decline of the social system in which they were born and the decay of the local courts in which they were enforced, but as early as the reign of Henry III Parliament began passing Statutes of the Realm

- A.B., I930, Duke University. Now a member of the third year class in the Duke University School of Law.

${ }^{2}$ Ilemwellym, Case and Materiats on Sates (1930) 204.

${ }^{2}$ Hamilton, The Ancient Maxim of Caveat Emptor (r93I) 40 YALE L. J. Ix33.

${ }^{5}$ I HEN. III, C. $6, \S_{3}(1267)$ S. ("'pillor', et tumbrel', et assiss' panis et cervis'"). 
regulating victualers and others of much the same character. A civil remedy was given the injured party by the courts, on the ground that the dealer had violated a statute for the protection of the public. ${ }^{4}$ Moreover, with the development of the remedy of assumpsit in the King's courts an additional ${ }^{5}$ basis for the obligation to sell pure food and drugs was found in the view that the "common victualer," in opening his shop, had undertaken the obligation to provide food fit to eat to his customers, which became an implied term of his contract. ${ }^{\circ}$ Cases before I800 are scarce, but it appears that recovery must have been unusual. Injuries may have been unusual also. Although the concept of the "common calling," originally applicable to all who held themselves out to do business with the public, is a narrowly restricted term today, an English decision as late as $I 847^{\top}$ limited recovery for defective food, in the absence of express warranty or fraud, to suits against dealers, as an obligation incident to their calling. ${ }^{8}$

With the coming of the industrial revolution and its accompanying accentuation of individualism, caveat emptor replaced the doctrine of the common calling, especially in American courts, ${ }^{9}$ and protection for consumers of food and drugs was a matter of exception to be granted guardedly. Thus, though Blackstone ${ }^{10}$ had recognized an implied warranty of fitness where food was sold, the Massachusetts court in $18 \mathrm{r} 3^{11}$ interpreted him to mean this to apply only where a dealer knew that he was selling impure food, and disguised it, a construction which appears to unduly limit Blackstone's text. ${ }^{12}$

The common law rules governing the liability of sellers, as they are applied today, were worked out chiefly in the nineteenth century by the same courts which were devising that harsh body of rules governing actions for personal injuries to employees which has since been swept away by workmen's compensation statutes. The spirit of the law was opposed to the imposition of liabilities which might handicap the expansion of business. ${ }^{13}$ Courts were slow to "imply" contractual undertakings not expressed by the parties. Liability without fault was a submerged concept in the law of torts.

'Cf. discussion of early law by Parke, B., in Burnby v. Bollett, I6 M. \& W. 644, 654, 153 Eng. Repr. 1348 , 1352 (1847).

'Warranty actions were first brought in tort for deceit but later assumpsit, a contract action, was used. Ames, Lectures on Legal History (1913) 136-r38.

- Burdick, The Origin of Duties Peculiar to Public Service Corporations, (I9I1) II Col. L. Rev. 514.

${ }^{7}$ Burnby v. Bollett, supra note 4 .

${ }^{8}$ In Emmerton v. Mathews, 7 H. \& N. 586, 158 Eng. Repr. 604 (1862), recovery was denied in a suit between dealers because it was not shown the seller knew his meat was defective, but recovery was allowed in Bigge v. Parkinson, 7 H. 8: N. 955, 158 Eng. Repr. 758 ( 1862 ), where plaintiff was a customer who relied on the dealer to pick out food products to be used as food for troops. There was an express warranty that the food should pass East India Company inspection, but the court said this did not negative implied warranty of fitness for food purposes.

${ }^{\circ}$ Hamilton, supra note 2 , at 1178 .

10 3 Blackstone, Commentaries, "165. 21 Emerson v. Brigham, xo Mass. I97 (1813).

12 "In contracts for provisions it is always implied that they are wholesome, and if they are not the same remedy may be had." 3 BLACKstone, supra note ro.

23 BOHLEN, Studies IN THE LAW OF TORTS (1926) 129. 
There were three legal theories available for the protection of the consumer. First, the seller could be held liable because he contracted to supply a good article (either on an express warranty or an implied warranty of fitness or merchantability) and broke his contract. Second, the party responsible for the impurity could be held for negligence in permitting or causing its existence, where this negligence was the proximate cause of the injury. Third, if the dealer knew of the defect, he could be held liable in the tort action for deceit, a remedy of little value to the consumer because of the difficulty in proving the dealer's knowledge.

The first is best exemplified today by the Uniform Sales Act, providing that $(x)$ where the buyer expressly, or by implication, makes known to the seller that he relies on his skill and judgment in the purchase of goods for a particular purpose, there is an implied warranty of fitness for that purpose, and (2) where the buyer purchases from a dealer "by description" there is implied warranty of merchantability. ${ }^{14}$ By further providing for the implication of these warranties regardless of whether the seller was a grower or manufacturer, the act brushes aside a limitation of such liability to those classes existing in a minority of American jurisdictions. ${ }^{15}$ Indeed, in some states, the implied warranty of merchantibility was not recognized, and only recently has it been realized that in food cases, at least, it may be coextensive with the warranty of fitness for food purposes. ${ }^{16}$ This fact may be of special significance when the housewife orders by brand name, as she is urged to do in page after page of national advertising, for the Sales Act, in accordance with decisions preëxisting it, excludes the warranty of fitness in that situation. ${ }^{17}$ But the warranty of merchantability, which may then be turned to, applies only to sales "by description." Where the purchaser instead of ordering, herself selects an article from a counter, it is doubtful whether the sale would be "by description," a loophole rendered important by some modern chain-store merchandizing practices. ${ }^{18}$ Moreover, it is doubtful whether the "description" is not satisfied where the entire brand is not "merchantable" (as may not be unlikely in the case of some proprietary medicines). ${ }^{19}$

Inspection by the purchaser will defeat recovery for defects that such examination should have revealed, a limitation whose uncertainty in application invites litigation. ${ }^{20}$ Where, as in the case of canned goods, it is obvious that the dealer has no knowledge of the quality of the goods he sells, some courts have denied recovery to

"Uniform Sales Act, $\$ \times 5$.

${ }^{15}$ I Williston, SAles (2d ed. rg24) $45 \mathrm{x}$.

${ }^{16}$ See Cardozo, C. J., in Ryan v. Progressive Stores, 255 N. Y. 388, 392, 175 N.E. 105, 106, 74 A.L. R. 339, 34r (193I).

${ }_{17}$ UNIFORM SALES ACT, \$15 (4).

${ }^{28}$ It is to be hoped that this differentiation is too fine-spun to be followed by a court. But the rule is that where the purchaser picks out the goods herself, there is no implied warranty. Farrell v. Manhattan Market, 198 Mass. 27 I, 84 N. E. 48 I, 15 L. R. A. (N. S.) 884 (1908).

${ }^{10}$ Note (I932) 45 HARv. L. Rev. 1415.

${ }^{20}$ It becomes a question of fact for the jury. Friend v. Child's Dining Hall Co., 23r Mass. 65, I20 N. E. 407,5 A. L. R. IIoo (1918); Farrell v. Manhattan Market, supra note I7. 
the buyer on the ground that he could not have relied on the seller's "skill and judgment."21

The intricacy of these rules, the unimportance of the factual differentiations upon which they are based, stand in sharp contrast to the informality of the normal retail transaction in which neither party knows or considers these legal consequences of his acts whose sequence may well be wholly fortuitous. Indeed, there is little likelihood that they will be accurately recalled when pending litigation and conferences with counsel reveal their significance. It is difficult to avoid the suspicion that the rules of the Sales Act were framed with more concern for wholesale transactions than for the over-the-counter retail purchase or the domestic order placed by telephone.22

But a still more serious limitation on the efficacy of the law of warranty as a means of consumer protection lies in the fact that neither the benefit nor the burden of the warranty "runs with the goods." It benefits only the purchaser, in principle and by the weight of authority, yet the whole family, their guests and servants may eat the defective food. Lack of privity of contract will prevent a recovery by the guests and servants, since the action on this theory must be on the contract. ${ }^{23}$ The husband can recover on grounds of agency where his wife or child was the purchaser, ${ }^{24}$ and if either of them suffers injury he may, perhaps, obtain damages for the loss of consortium or services and for the cost of medical care furnished them. ${ }^{25}$

Since the retail seller may frequently be judgment-proof, ingenious efforts have been recently made to hold manufacturers or distributors as express warrantors, by virtue of advertising or labels. ${ }^{26}$ A manufacturer has been held liable to the final purchaser of an automobile, on the ground that his advertisement of "Shatter-proof" glass was an express warranty, ${ }^{27}$ and in Mississippi the manufacturers of "Baby Ruth"

${ }^{21}$ Kroger Grocery Co. v. Lewilling, I65 Miss. 7r, 145 So. 726 (r933); Bigelow v. Maine Central R. R., I10 Me. I05, 85 A. 396, 43 L. R. A. (N. S.) 627. Contra: Ward v. Great Atlantic \& Pacific Tca Co., 231 Mass. 90,120 N. E. 225, 5 A. L. R. 242 (rgr8). The view that the dealer is not a warrantor secms to fly in the teeth of the wording of the Sales Act.

${ }^{22}$ Even the rules of the Sales Act, in force in 30 states, are more favorable to consumers than the common law rules of some states governing warranty. I Willisron, op. cit. supra note 15, at 499. "Remedies of injured consumers ought not to be made to depend on the intricacies of the law of sales. . . . It should rest . . . upon 'the demands of social justice." " Ketterer v. Armour, 200 F. 322, 323 (S. D. N. Y. 1912) (holding manufacturer liable to consumer in tort).

${ }^{23}$ I Williston, op. cit. supra note 15 , at 487 . Contra: Davis v. Van Camp Packing Co., I8g lowa 775; I76 N. W. 382, I7 A. L. R. 649 (1920); Hertzler v. Manshum, 228 Mich. 416, 200 N. W. 155 (1924).

${ }^{24}$ Ryan v. Progressive Stores, supra note 26.

${ }^{25}$ Kennedy v. Woolworth, 205 App. Div. 648, 200 N. Y. Supp. 12I (1923) (child). Contra: Rode v. Arney, 115 Ill. App. 629 (I904) (husband cannot counterclaim for loss of wife's services, in suit on notes given for defective wagon, which broke, injuring wife). The general rule is that plaintiff who is in privity of contract and thus a party to the warranty, can recover damages which are the natural consequences of the defect. 2 Williston, op. cit. supra note 15, at 1542. But the child, Redmond v. Borden's Farm Products Co., 245 N. Y. 512, I57 N. E. 838 (I927), the wife, Gearing v. Berkson, 223 Mass. 257, III N. E. 785, L. R. A. I9I6D 1006 (I9I5), and the servant, Chysky v. Drake Bros., 235 N. Y. 468,139 N. E. 576, 27 A. L. R. I53 (1923) cannot recover in their own names in a warranty suit.

' I Williston, op. cit. supra note 15, at 490, Sholley, Manufacturer's Advertisement as Express Warranty (1932) 7 WASH. L. REv. 35I, Llewellyn, op. cit. supra note 1 , at 389 .

"II Baxter v. Ford Motor Co., I68 Wash. 456, 12 P. (2d) 409 (1932). The court said, p. 412 , "Since the rule of caveat emptor was first formulated, vast changes have taken place in economic structures of 
candy bars have been held to an implied warranty, on the basis of advertising, despite the privity of contract rule. ${ }^{28}$ But in earlier cases where the same argument was attempted a manufacturer of bread in which a pin was found was held not liable, even though he labeled the bread "guaranteed after thorough inspection," since the guarantee was construed to apply only to the purity of ingredients used, and not to be a guaranty against the presence of foreign matter, a tenuous distinction. ${ }^{29}$

But regardless of whether there is a warranty, if negligence can be proven there can be a recovery, and it is in actions based on this theory that the manufacturer or distributor can best be reached and that the injured non-purchaser may obtain compensation. ${ }^{30}$ Even this liberality represents an exception in the rule that there must be privity of contract for recovery against a manufacturer of goods, even in tort actions. ${ }^{31}$ This notion entered tort law through the concept proximate cause, with the idea that the intermediate sale broke the chain of causation. Until the day of packaged goods and national advertising, moreover, the purchasers' actual protection was probably the dealer's judgment and inspection. But in the United States, this limitation has not been applied in favor of negligent manufacturers of food and drugs since the case of Thomas $v$. Winchester ${ }^{22}$ in New York in I852. Here a recovery was allowed against a manufacturer who mislabeled a drug negligently, where the plaintiff was a consumer without contractual relations. This rule is followed in all common-law jurisdictions, although it was not adopted by the House of Lords until 1932, and then only with vigorous dissent, in a case where a mouse was immured in a ginger-beer bottle. ${ }^{33}$.

The difficulty in proving negligence in these cases is a formidable obstacle. The

the English speaking peoples. Methods of doing business have undergone a great transition. Radio, billboards and the products of the printing press have become the means of creating a large part of the demand that causes goods to depart from factories to the ultimate consumer. It would be unjust to recognize a rule that would permit manufacturers to create a demand for their products by representation that they possess qualities which they in fact do not possess, and then, because there is no privity of contract existing between the consumer and manufacturer, deny that consumer the right to recover if damage results from the absence of those qualities when such absence is not readily noticeable."

" Curtiss Candy Co. v. Johnson, 163 Miss. 426, I4x So. 762 (1932). The court here holds there is an implied warranty by a manufacturer of food products on which the consumer can sue, relying on defendant's advertising, and also holds that dealers, with no opportunity to examine the contents of the package, are not liable as warrantors.

${ }^{2}$ Pelletier v. Du Pont, I24 Me. 269, 128 A. I86, 39 A. L. R. 972 (1923).

${ }^{80}$ Broadway v. Grimes, 204 N. C. $623, \times 69$ S. E. 194 (I933). The superiority of the remedy on the warranty, where available, is shown by two Massachusetts cases, on practically identical facts, where the counsel who brought his action on the contract won, Friend v. Childs Dining Hall Co., suspra note I9, and the counsel who sued in tort failed for failure of proof of negligence, Ash v. Childs Dining Hall Co., 231 Mass. 86, I20 N. E. 396, 4 A. L. R. 1556 (I9I8). See note (I9I8) 33 HARv. L. Rev. 24I. Some states where the vendor is a restaurant deny liability on a warranty entirely, on the ground that services, not goods, are being sold. I WILIISToN, op. cit. supra note I5, at 485 .

"MacPherson v. Buick Motor Co., 2I7 N. Y. 382, III N. E. IO50 (I9I6) BoHLEN, op. cit. supra note I3, Iog.

3 N. Y. 397 (1852).

${ }^{33}$ M'Alister v. Stevenson [I932] A. C. 562. Lord Atkin concluded his opinion, "It is a proposition which I venture no one in Scotland or England who is not a lawyer would for one moment doubt. It will be an advantage to make clear that the law in this matter as in most others is in accordance with common sense." 
plaintiff may often be exposed to a non-suit or a directed verdict against him for want of sufficient evidence to establish it. The rule of tort law, that where normally an injury would not occur without negligence and where the means of preventing it or explaining its cause are exclusively within the control of the defendant, the plaintiff need not introduce evidence of negligence, would afford him some protection from this hazard if it were applied here, yet this doctrine of res ipsa loquitur has been applied to food and drug cases by only a minority of jurisdictions. ${ }^{34}$ Its rejection is mitigated in other jurisdictions by the fact that evidence of the presence of a foreign substance in food and drugs establishes a prima facie case. ${ }^{35}$ Moreover, in those cases where the question is submitted to the jury, jurors are permitted to use their own experience and reasonable inferences in deciding whether impurities entered through the negligence of the manufacturer in jurisdictions which follow neither the res ipsa loquitur nor the prima facie rule. ${ }^{36}$

Violation of a pure food and drug act has been held sufficient to show negligence and permit a recovery since these statutes are enacted for the public's protection from the very harm suffered. ${ }^{37}$ Consequently, if the pure food and drug act is made broad enough, the difficulties of proof in negligence actions largely disappear. The New York Farm and Markets act, for example, has been applied to permit a recovery where there was no privity of contract under holdings that it was negligence as a matter of law to market impure poultry feed, since it was prohibited by statute. ${ }^{\mathbf{3 8}}$ In a later decision the New York Court of Appeals expressly left open the question of the application of this statute to a purchase of bread. ${ }^{39}$ Yet the use of such statutes for this purpose is perhaps the only device that is broad enough to give customers sufficient protection under modern marketing conditions, where goods are bought in packages whose past history may be undiscoverable, where customers cannot tell

34 Schneider, Presumptive Rule of Negligence (I933) I3 B. U. L. REv. 50, 58.

${ }^{25}$ Cases on the problem are collected in Notes (1919) 4. A. L. R. 1559 and (1927) 47 A. L. R. 148. The Massachusetts rule in Ash v. Childs Dining Hall Co., supra note 29, is criticized as making proof too difficult for the injured plaintiff in 5 WIGMORE, EvideNCE (2d ed. 1923) 496.

${ }^{28}$ Tonsman v. Greenglass 248 Mass. 275, 142 N. E. 756 (I924), Minutilla v. Providence Ice Cream Co., 50 R. I. 43 , I44 Atl. 884,63 A. L. R. 334 (I929).

${ }^{87}$ Meshbesher v. Channellene Oil \& Mfg. Co., ro7 Minn. I04, II9 N. W. 428 (Ig09); Kellcy v. John R. Daily Co., 56 Mont. 63, I8r Pac. 326 (Igrg); Armour v. Wannamaker, 202 Fed. 423 (C. C. A. 3d, I913). In South Carolina there is confusion. Cf. Tate v. Mauldin, 157 S. C. 392, 154 S. E. 431 (1930), and Burnette v. Augusta Coca-Cola Bottling Co., 157 S. C. 359, 154 S. E. 645 (1930), with Culbertson v. Coca Cola Bottling Co., I57 S. C. 352, 154 S. E. 424 (I930). The tendency of the courts is to use the pure food laws as a makeweight, after finding a common law or statutory sales law ground for liability in warrantory or tort. Cf. Mazetti v. Armour \& Co., 75 Wash. 622, 135 Pac. 633, 48 L. R. A. (N. S.) 213, (1913) Ward v. Morehead City Sea Food Co., 17I N. C. 33, 87 S. E. 958 (1916) (a distinct ground of decision, but not mentioned in later North Carolina cases) and Ryan v. Progressive Stores, supra note 16, where the New York court found it unnecessary to inquire if the statute applied. The pending Copeland Bill, 73rd Cong., Ist. Sess., S. 1944, \$24, gives a civil remedy to all persons for injuries or death resulting from violation of the Act, but this result would probably follow in any event. This theory has not been of greater use in the past, perhaps, because pure food laws either required knowledge as an essential element of violation or were limited in scope.

${ }^{23}$ Pine Grove Poultry Farm v. Newton By-Products Co. 248 N. Y. 293 , 162 N. E. 84 (1928).

${ }^{\infty}$ Ryan v. Progressive Stores, supra note I6. 
when they buy whether or not the goods are wholesome, and where the local dealer knows little more thanthey do, and in addition is probably near insolvency.

Another solution would be to make all dealers and manufacturers of food and drugs insurers of wholesomeness, which is done in some jurisdictions in the case of restaurants. ${ }^{40}$ But the courts could scarcely do this without legislation, and pure food and drug legislation, construed with the same solicitude for human consumers as was the New York Farm and Markets Act for poultry, would achieve the same beneficial result. A further possibility for a remedy against a manufacturer lies in holding that his warranty to the dealer is a contract on which the consumer may sue as a third party beneficiary. ${ }^{41}$

The recent increase in cases of food and drug injuries indjcates, however, a need for protection against hold-up suits as well as for protection for the helpless consumer. This protection is supplied in theory at least by requiring a connection between the impurity in the food or drug and the injury. Medical testimony may be relied on for this. ${ }^{42}$ The courts will even consider the state of the consumer's health as described by his application for life insurance. ${ }^{43}$ Contributory negligence is a defense in a negligence action, and a consumer cannot recover for injury, even in warranty, if he deliberately ate bad food after discovering the defect. Damages for fright and shock, unless the fright causes a physical injury, are not allowed, ${ }^{44}$ and thus a fruitful source of hold-up suits is stopped. Manufacturers and dealers may, moreover, spread the losses resulting from impure products, through insurance or through raising their price level slightly. The injured consumer cannot anticipate his loss or minimize its consequences, except by a recovery against dealer, distributor or manufacturer. Imposition of liability will tend to make tradesmen careful.

In the hands of a court imbued with the idea that the common law can change to meet changing conditions, and firmly convinced that conditions have changed greatly since the days when the obligations of sellers became fixed, the common law remedies for injured consumers can prove adequate. But today the injured persons face rather the possibility of a test case, for the more stringent rules imposing liability are not yet decided law in most jurisdictions, and besides the aid of an able physician to heal his injuries, he must have an able and industrious attorney to chart his way through the maze of conflicting theories and old precedents which may operate to bar him from damages. But the average injured consumer is not equipped for such legal battle. Like the average injured employee, or victim of an automobile accident, he needs a clear law, imposing liability, which will induce those who supplied him with food or drugs to settle quickly, rather than the chance that the court will, consciously or unconsciously, change the law to meet changed conditions.

${ }^{\infty}$ Smith v. Carlos, 215 Mo. App. 485,247 S. W. 468 (r923).

4 Ward Baking Co. v. Trizzino, I6I N. E. 557 (Oh. App., I928).

"Harper v. Bullock, 198 N. C. 448 , 152 S. E. 405 (1930).

"McCabe v. Pennsylvania R. Co., 3II Pa. 229, I66 A. 843 (1933).

"Kenney v. Wong Len, 81 N. H. 427, 128 A. 343 (1925). The rule in some states that there can be no recovery for fright unless it is accompanied by physical injury would apply in these cases. 